\title{
HUBUNGAN KETIDAKPUASAN TUBUH DENGAN PENERIMAAN DIRI PADA PEREMPUAN USIA DEWASA AWAL (18 - 25 TAHUN) DI KOTA MALANG
}

\author{
${ }^{1}$ Ani Latifatul Khoiriyah dan ${ }^{2}$ Aprilia Mega Rosdiana \\ 1,2UIN Maulana Malik Ibrahim Malang \\ 1anilatifatulk@yahoo.com \\ 2apriliamegarosdiana@gmail.com
}

\begin{abstract}
The purpose of this study was to determine the relationship between body dissatisfaction with self-acceptance in early adult women (18-25 years). Selfacceptance is a condition where the individual has a positive attitude towards himself and is able to accept himself with all the advantages and disadvantages. People who are not able to convince themselves positively means less able to accept the deficiencies that exist in themselves so they feel less satisfied with him. Dissatisfaction with the body or the Body Dissatisfaction is one that is often experienced by women today. This study uses quantitative research methods with incidental sampling techniques. The subjects in this study were early adult women (18-25 years) in Malang City. The results of this study indicate that studies of adult women (18-25 years) have the same high Body Dissatisfaction and SelfAcceptance, this is proven to be related to a positive relationship, with a coefficient value of $0.226>$ r table of 0.202.
\end{abstract}

Keywords: Body Dissatisfaction, Self Acceptance, Early Adult Women (18-25 years).

\section{Abstrak}

Tujuan penelitian ini dilakukan adalah untuk mengetahui hubungan antara ketidakpuasan tubuh dengan penerimaan diri pada perempuan usia dewasa awal (18 - 25 tahun). Penerimaan diri merupakan keadaan dimana individu memiliki sikap positif terhadap dirinya dan mampu menerima dirinya dengan segala kekurangan dan kelebihannya. Orang yang tidak mampu bersikap positif terhadap dirinya berarti kurang mampu menerima kekurangan yang ada pada dirinya sehingga merasa kurang puas terhadap dirinya. Ketidakpuasan terhadap tubuh atau Body Dissatisfaction merupakan salah satu permasalahan yang sering dialami oleh perempuan masa kini. Penelitian ini menggunakan metode penelitian kuantitatif dengan teknik pengambilan data sampling insidential. Subjek dalam penelitian ini merupakan perempuan usia dewasa awal $(18-25$ tahun) di Kota Malang. Hasil penelitian ini menunjukkan bahwa mayoritas perempuan usia dewasa awal (18 - 25 tahun) memilik Ketidakpuasan Tubuh dan Penerimaan Diri yang sama tinggi, hal ini terbukti bahwa keduanya 
memiliki hubungan yang positif, dengan nilai koefisien korelasi sebesar 0,226 > $r$ tabel 0,202.

Kata Kunci: Ketidakpuasan Tubuh, Penerimaan Diri, Perempuan Usia Dewasa Awal (18 - 25 tahun)

\section{PENDAHULUAN}

Kecantikan adalah salah satu problematika kehidupan yang selalu dialami oleh banyak perempuan. di Indonesia, perempuan sendiri selalu dicekoki dengan iklan-iklan kecantikan yang menampilkan sosok perempuan yang ideal, dimana perempuan cantik adalah perempuan yang memiliki kulit putih, langsing, dan menawan. Sehingga banyak perempuan yang ingin mempercantik dirinya dan merubah dirinya, salah satunya adalah perempuan di kota Malang. Malang adalah kota terbesar di Jawa Timur setelah kota Surabaya. Seperti kota besar lainnya, Malang memiliki banyak penduduk urbanisasi. Di Malang sendiri banyak perempuan-perempuan yang menginginkan kulit cerah dan putih, seperti yang dikutip dari MalangTIMES (2017) bahwa perempuan di kota Malang untuk mendapatkan kulit yang cerah secara instan mereka rela memakai krim pemutih yang membahayakan kesehatan kulit mereka. Nilai budaya lokal juga menilai "putih" sebagai kebaikan berpadu dengan standar ideal Barat tentang kecantikan. Banyak perempuan saat ini yang merasa kurang senang dengan tubuhnya kemudian memakai produk pemutih badan dan wajah yang memiliki cara kerja yang cepat agar terlihat menawan dan menarik perhatian orang lain karena salah satu titik insecure terbesar perempuan ada pada penampilan fisiknya.

Menurut Thompson (2008) Setiap individu memiliki keinginan untuk berpenampilan sempurna di depan orang-orang, keinginan inilah yang dapat membuat kekhawatiran seseorang timbul dan kekhawairan ini akan menjadikan seorang individu melakukan hal-hal agar penampilannya terlihat menarik seperti apa yang diinginkan, karena bagi individu tampilan yang menarik dapat menentukan sebuah kesan yang membentuk diri individu tersebut dan mampu membangun jalan hubungannya dengan orang lain. Menurut Supratiknya (1995) untuk membangun dan melestarikan sebuah hubungan dengan sesama, maka individu harus mampu menerima dirinya dan juga menerima orang lain yang ada di lingkungan sekitarnya.

Penerimaan diri merupakan sebuah patokan sejauh mana individu mampu menerima karakter personal yang dimilikinya dan menggunakannya untuk menjalani kelangsungan hidup. individu yang dapat menerima dirinya akan mengetahui potensinya dan bebas untuk menggunakannya, dan juga menegetahui kekurangan pada dirinya tanpa menyalahkan dirinya sendiri 
(Gunarsa, 1999). Meilinda (2013) menyatakan bahwa penerimaan diri merupakan keadaan dimana seseorang memiliki sikap yang positif terhadap dirinya sendiri dengan mengakui dan menerima dirinya dalam berbagai aspek diri termasuk kualitas yang baik dan buruk, merasa positif dengan kehidupan yang dijalani. Supratiknya (1995) berpendapat bahwa yang dimaksud dengan menerima diri adalah memiliki penghargaan yang tinggi terhadap diri sendiri, atau lawannya, tidak bersikap sinis terhadap diri sendiri.

Aspek-aspek penerimaan diri menurut Supratiknya (1995) yaitu : (1) Kerelaan untuk membuka atau mengungkapkan aneka pikiran, perasaan, dan reaksi kepada orang lain. (2) Kesehatan psikologis. (3) Penerimaan terhadap orang lain. Selain itu Hurlock (2008) juga mengungkapkan beberapa faktor yang membentuk penerimaan diri seseorang, yaitu: pemahaman diri, harapan yang realistis, tidak adanya hambatan dari luar, sikap sosial yang positif, tidak adanya stres yang berat, pengaruh keberhasilan, dan konsep diri yang stabil.

Johada (dalam Rizkiana \& Retnaningsih, 2009) menyatakan bahwa penerimaan diri berarti seorang individu telah mampu belajar untuk hidup dan dirinya sendiri, dalam artian individu sudah dapat menerima kelebihan maupun kekurangan yang ada dalam dirinya. Hal ini lah yang sebenarnya dibutuhkan oleh perempuan, dimana mereka harus mampu menerima diri mereka sendiri bahwa di dalam diri mereka terdapat kekurangan dan kelebihan yang mampu dikembangkan. Penelitian yang digagas oleh Harvard University yang bekerjasama dengan Dove, sebuah merek produk yang berkomitmen pada perawatan kecantikan perempuan, menyebutkan bahwa hanya sekitar $2 \%$ perempuan didunia ini dan tidak sampai 3\% perempuan Asia yakin dan menganggap bahwa diri mereka cantik, di negara Indonesia sendiri tidak sampai $40 \%$ perempuan merasa nyaman dengan kecantikan yang dimiliki, dalam hal ini arti dari kecantikan dinilai berdasar perilaku perempuan terhadap beberapa hal, salah satunya penampilan tubuh (Moernantyo, 2005). Menurut BrooksGunn \& Paikoff (dalam Santrock, 2002), ketidakpuasan pada tubuh atau body dissatisfaction banyak dialami oleh remaja perempuan dibandingkan oleh remaja laki-laki. Kemudian terdapat suatu penelitian yang dilakukan oleh Levine \& Smolak (dalam Meilinda, 2013) yang menyatakan bahwa $40-70 \%$ remaja perempuan merasakan ketidakpuasan pada dua atau lebih dari bagian tubuhnya, khususnya pada bagian pinggul, pantat, perut dan paha. Menurut hasil survey yang dilakukan peneliti kepada 100 responden perempuan remaja dan dewasa awal kebanyakan dari mereka memang mengalami masalah dalam ketidakpuaasan terhadap tubuhnya namun pada usia dewasa awal mereka masih mampu menerima dirinya walaupun merasa kurang puas terhadap tubuhnya, sedangkan remaja lebih tidak mampu menerima dirinya dan kurang puas terhadap tubuhnya. Menurut Edward 
(dalam Hanum dkk, 2014), remaja masih memiliki beberapa kebutuhan yang menuntut agar terpenuhi, kebutuhan tersebut adalah: (1) kebutuhan untuk mencapai sesuatu, (2) kebutuhan ingin terkenal di lingkungannya, (3) kebutuhan akan kebebasan untuk menentukan sikap sesuai dengan kehendaknya, (4) kebutuhan untuk mencari bantuan dan simpati. Sedangkan menurut Andi Mappiare (1983) dewasa awal adalah masa dimana seseorang mengalami kematangan dalam fisik dan psikologisnya, ada beberapa ciri-ciri kematangan psikologis itu sendiri, yakni: (1) memiliki tujuan-tujuan yang jelas, (2) mampu mengendalikan perasaan-peasaan pribadi, (3) menerima kritik dan saran dari orang lain. Keadaan remaja dan dewasa awal berbeda, remaja lebih fluktuatif dan tidak stabil jika dibandingkan dengan yang telah menginjak masa usia dewasa awal dimana orang dewasa awal lebih logis dalam berpikir dan mampu menempatkan diri dengan kenyataan yang telah dihadapinya (Orth, Trzesniewski, \& Robins, 2010).

Herawati (dalam Suprapto \& Aditomo, 2007) melakukan penelitian di Jakarta pada tahun 2003, didapatkan informasi bahwa sebanyak 40\% perempuan berusia 18-25 tahun mengalami ketidakpuasan tubuh dalam kategori tinggi, dan 38\% dalam kategori sedang. Seorang yang mengalami ketidakpuasan tubuh biasanya berpikiran bahwa penampilan fisik yang menarik adalah dengan memiliki wajah yang cantik, serta berat badan dan bentuk tubuh yang ideal. Kepuasan atau ketidakpuasan terhadap tubuh dan bagian-bagian tubuh merupakan bagian dari cara seseorang memaknai anggota tubuhnya sebagai fungsi atau sebagai objek keindahan. Orang yang memiliki kecenderungan ketidakpuasan terhadap tubuh biasanya akan sibuk membesarbesarkan kekurangan fisiknya yang sebenarnya tidak nyata, dari sinilah kemudian memunculkan rasa tidak percaya diri dan memunculkan masalah dalam penerimaan dirinya.

Body dissatisfaction atau ketidakpuasan pada bentuk tubuh menurut Asih dan Setiasih (2004) adalah keterpakuan pikiran akan penilaian yang negatif terhadap tampilan fisik dan adanya perasaan malu dengan keadaan fisik ketika berada di lingkungan sosial. Adlerd (2006) juga berpendapat bahwa ketidakpuasan tubuh adalah perbedaan antara persepsi individu mengenai ukuran tubuh ideal dan ukuran tubuh mereka yang sebenarnya, perbedaan antara persepsi mereka tentang ukuran sebenarnya mereka bandingkan dengan ukuran ideal mereka atau sebagai perasaan ketidakpuasan dengan ukuran bentuk tubuh. Menurut Rosen \& Reiter (dalam Risfani \& Makmuroh, 2015), ketidakpuasan tubuh adalah keterpakuan pikiran akan penilaian yang negatif terhadap penampilan fisik dan adanya perasaan malu dengan keadaan fisiknya ketika berada di lingkungan sosial. Ketidakpuasan tubuh menurut Hall (2009), ialah evaluasi negatif seseorang terhadap tubuhnya. Individu menilai 
dan mempersepsikan negatif terhadap tubuhnya, yakni merasa tidak memiliki tubuh yang bagus.

Menurut Rosen \& Riter (dalam Risfani \& Makmuroh, 2015), aspek-aspek dari ketidakpuasan pada bentuk tubuh diantaranya adalah : (1) Penilaian negatif terhadap bentuk tubuh. (2) Perasaan malu terhadap bentuk tubuh ketika berada di lingkungan sosial. (3) Body Checking. (4) Kamuflase tubuh. (5) Penghindaran aktivitas sosial dan kontak fisik dengan orang lain. Sementara itu ada juga faktor yang mempengaruhi ketidakpuasan tubuh Menurut Bremh (dalam Kartikasari 2013) diantaranya yaitu : Standar kecantikan yang tidak mungkin dicapai, percaya bahwa kontrol terhadap diri akan menghasilkan tubuh yang sempurna, ketidakpuasan yang mendalam terhadap diri sendiri dan kehidupan, kebutuhan akan kontrol karena banyak hal yang tidak dapat dikontrol, dan hidup dalam budaya "first impressions (kesan pertama)".

\section{METODE PENELITIAN}

Penelitian ini menggunakan metode penelitian kuantitatif dengan variabel bebas $(\mathrm{X})$ ketidakpuasan tubuh dan variabel terikat (Y) Penerimaan Diri. Subjek pada penelitian ini adalah perempuan usia dewasa awal (18 - 25 tahun) di Kota Malang dengan ukuran sampel 100 responden. Pengambilan sampel menggunakan teknik sampling Insidental yakni suatu teknik untuk menentukan sampel berdasarkan anggota populasi yang ditemui peneliti secara kebetulan dan bersedia menjadi subjek penelitian, dimana subjek yang ditemui secara kebetulan tersebut cocok atau sesuai dengan kriteria populasi (Sugiyono, 2016).

Instrument yang digunakan dalam penelitian ini untuk mengukur skala ketidakpuasan tubuh yang terdiri dari 42 aitem, dengan rincian 12 aitem (pada aspek penilaian negatif terhadap bentuk tubuh individu), 12 aitem (pada aspek perasaan malu terhadap bentuk tubuh ketika berada di lingkungan sosial), 6 aitem (pada aspek body checking), 6 aitem (pada aspek kamuflase tubuh), 6 aitem (pada aspek penghindaran aktivitas sosial dan kontak fisik dengan orang lain). Sementara untuk mengukur skala penerimaan diri terdiri dari 36 aitem, dengan rincian 12 aitem (pada aspek kerelaan untuk membuka atau mengungkapkan aneka pikiran, perasaan, dan reaksi kepada orang lain), 12 aitem (pada aspek kesehatan psikologis), 12 aitem (pada aspek penerimaan terhadap orang lain).

Uji reliabilitas pada skala ketidakpuasan tubuh menunjukan koefisien sebesar 0,864 (Alpha Cronbach). Sedangkan uji reliabilitas pada skala penerimaan diri menunjukan koefisien sebesar 0,849 (Alpha Cronbach). Metode analisis data yang digunakan dalam penelitian ini adalah analisis deskriptif statistik, analisis uji asumsi, analisis uji hipotesis serta analisis koralasi product 
moment. Analisis korelasi product moment ini digunakan untuk mengetahui ada atau tidaknya hubungan independent variabel (ketidakpuasan tubuh) dengan dependent variabel (penerimaan diri).

\section{HASIL PENELITIAN}

\section{Analisis Statistik Deskriptif}

Adapun nilai hasil statistik dekskriptif adalah sebagai berikut:

Tabel 1. Skor Hipotetik dan skor Empirik

\begin{tabular}{cccccccccc}
\hline Variabel & N & \multicolumn{3}{c}{ Skor Hipotetik } & \multicolumn{4}{c}{ Skor Empirik } \\
Maks & Mean & SD & Min & Maks & Mean & SD \\
\hline $\begin{array}{c}\text { Ketidakpuasan } \\
\text { Tubuh }\end{array}$ & 100 & 27 & 135 & 81 & 18 & 65 & 135 & 80 & 12 \\
\hline $\begin{array}{c}\text { Penerimaan } \\
\text { diri }\end{array}$ & 100 & 24 & 120 & 72 & 16 & 65 & 120 & 79 & 10 \\
\hline
\end{tabular}

Tabel 2. Kategorisasi Data

\begin{tabular}{lcc}
\hline \multicolumn{1}{c}{ Kategorisasi } & Ketidakpuasan Tubuh & Penerimaan Diri \\
\hline Tinggi & 16 & 8 \\
\hline Sedang & 84 & 92 \\
\hline Rendah & 0 & 0 \\
\hline
\end{tabular}

Berdasarkan dari tabel 1 dan 2 di atas, didapatkan bahwa responden yang memiliki ketidakpuasan tubuh pada kategori tinggi berjumlahkan 16 responden (16\%). Kemudian pada kategori sedang terdapat 84 responden (84\%). dan sementara pada kategori rendah hanya ada 0 responden $(0 \%)$. Sedangkan penerimaan diri pada kategori tinggi berjumlahkan 8 responden (8\%). Kemudian pada kategori sedang terdapat 92 responden (92\%). Dan sementara pada kategori rendah terdapat 0 responden $(0 \%)$.

\section{Analisis Uji Asumsi}

Tabel 3. Hasil Uji Normalitas

\begin{tabular}{cccc}
\hline Variable & $\begin{array}{c}\text { Komogrov- } \\
\text { Smirnov }\end{array}$ & $\begin{array}{c}\text { Shapiro- } \\
\text { Wilk }\end{array}$ & Keterangan \\
\hline Ketidakpuasan tubuh & 0,200 & 0,689 & Normal \\
\hline Penerimaan diri & 0,000 & 0,000 & Tidak Normal \\
\hline
\end{tabular}

Berdasarkan table 3 di atas dapat diketahui bahwa ketidakpuasan tubuh memiliki sig. Komogrov-Smirnov sebesar 0,200 dan Shapiro-Wilk sebesar 0,689, 
hasil ini menyatakan bahwa variabel ketidakpuasan tubuh memiliki probabilitas $>0,05$ sehingga dinyatakan Normal. kemudian penerimaan diri memiliki sig. Komogrov-Smirnov sebesar 0,000 dan Shapiro-Wilk sebesar 0,000, hasil ini menyatakan bahwa variabel penerimaan diri memiliki probabilitas $<0,05$ sehingga dinyatakan Tidak Normal.

Tabel 4. Hasil Uji Linieritas

\begin{tabular}{ccc}
\hline Variable & F & Sig. \\
\hline $\begin{array}{c}\text { ketidakpuasan } \\
\text { tubuh*Penerimaan diri }\end{array}$ & 0,566 & 0,962 \\
\hline Keterangan & Linier & Linier \\
\hline
\end{tabular}

Berdasarkan tabel 4 di atas, didapatkan nilai signifikasi Sig. (p) 0,962 > 0,05 . Maka dapat dikatakan bahwa adanya hubungan linier yang signifikan antara variabel ketidakpuasan tubuh dan variabel penerimaan diri.

\section{Uji Hipotesis}

Tabel 5. Hasil Uji Hipotesis

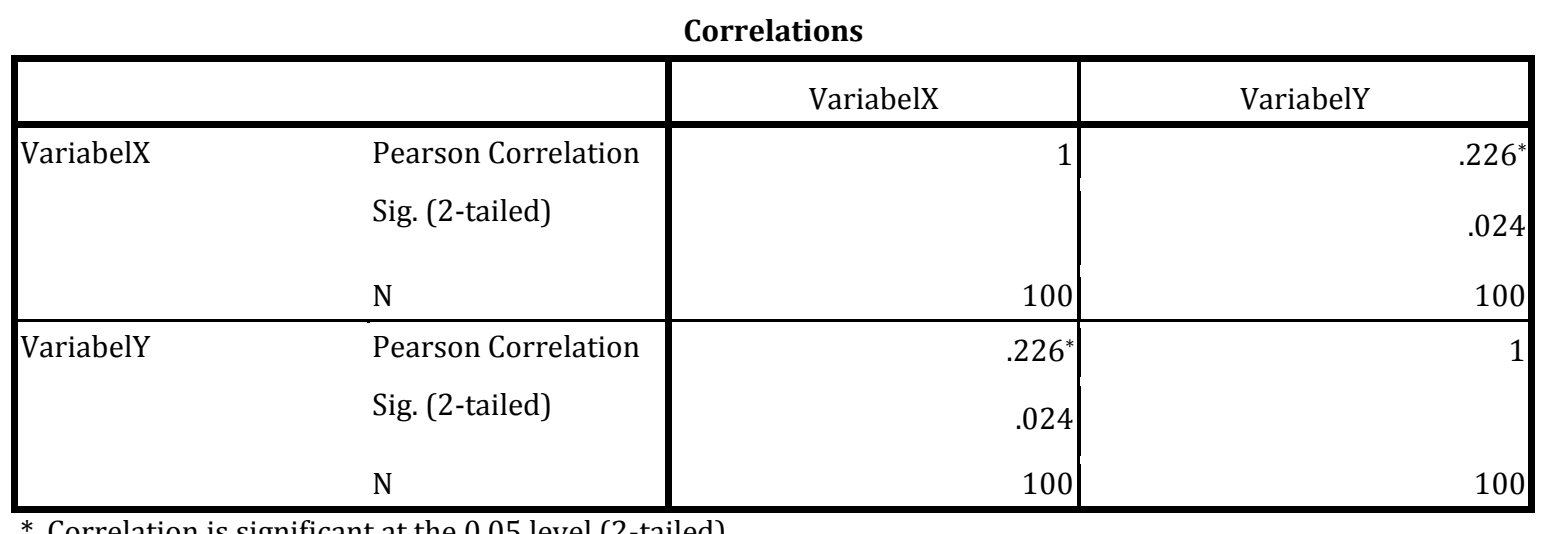

*. Correlation is significant at the 0.05 level (2-tailed).

Berdasarkan hasil dari table 5 hasil uji pearson korelasi di atas, dapat dianalisis bahwa korelasi antara body dissatisfaction dan penerimaan diri diperoleh $r=0,226$ dengan nilai signifikasi $\mathrm{p}=0,024<0,05$. Hal ini menunjukan bahwa terdapat hubungan yang signifikan antara ketidakpuasan tubuh dengan penerimaan diri dan memiliki arah hubungan korelasi bersifat positif, yang berarti bahwa seorang perempuan usia dewasa awal tersebut ketidakpuasan terhadap tubuhnya tinggi, dan penerimaan diri mereka juga tinggi.

\section{PEMBAHASAN}


Tingkat ketidakpuasan tubuh pada perempuan usia dewasa awal (18 25 tahun) di Kota Malang dominan berada pada kategori sedang dengan presentase $84 \%$. Perempuan usia dewasa awal di kota malang ini kebanyakan memiliki tingkat ketidakpuasan tubuh sedang. Menurut Brehm (dalam Iswari \& Hartini, 2005) ada beberapa faktor yang mempengaruhi ketidakpuasan tubuh seseorang, yaitu : 1) hidup dalam budaya; 2) standar kecantikan yang mungkin tidak dapat dicapai; 3) ketidakpuasan yang mendalam terhadap diri sendiri dan kehidupan; 4) kepercayaan atau keyakinan bahwa kontrol terhadap diri akan menghasilkan tubuh yang sempurna; 5) kebutuhan akan kontrol karena banyak hal yang tidak dapat dikontrol.

Tingkat penerimaan diri pada perempuan usia dewasa awal (18 - 25 tahun) di Kota Malang dominan pada kategori sedang dengan presentase 92\%. Perempuan usia dewasa awal di Kota Malang ini juga kebanyakan memiliki tingkat penerimaan diri yang sedang sama seperti ketidakpuasan tubuh. Menurut Allport (dalam Dewi, 2017) bahwa individu yang memiliki penerimaan diri yang baik maka juga memiliki gambaran yang positif tentang dirinya, dapat mengatur rasa frustasi dan kemarahan, dapat berinteraksi dan dapat menerima kritikan dari orang lain, dan juga data mengatur keadaan emosi (depresi dan kemarahan).

Hasil analisis yang dilakukan telah diperoleh hasil tabel korelasi antara variabel ketidakpuasan tubuh dengan penerimaan diri pada perempuan usia dewasa awal (18 - 25 tahun) adalah sebesar 0,226 > r tabel 0,202 dan nilai signifikasi sebesar $0,024<0,05$. Hal tersebut menunjukkan bahwa terdapat hubungan atau korelasi yang signifikan antara variabel ketidakpuasan tubuh dengan penerimaan diri. Karena $r$ hitung atau Pearson Correlation dalam analisis ini bernilai positif (tidak ada tanda negatife (-)) maka itu artinya hubungan antara kedua variabel ini tersebut bersifat positif, dimana artinya adalah semakin tinggi ketidakpuasan tubuh yang dimiliki oleh seorang perempuan usia dewasa awal (18 - 25 tahun) ini maka akan tinggi pula penerimaan diri mereka, dan begitu juga sebaliknya. Jika semakin rendah ketidakpuasan tubuh yang dimiliki maka semakin rendah juga penerimaan diri. Oleh karena itu hipotesis dalam penelitian ini dinyatakan diterima karena hasil tersebut menunjukan adanya hubungan positif antara ketidakpuasan tubuh dengan penerimaan diri pada perempuan usia dewasa awal.

Tylka dan Sabik (dalam Livian, dkk, 2012) menyatakan bahwa perempuan yang sering mengamati tubuhnya sendiri dan membandingkan tubuhnya dengan tubuh perempuan lainnya akan merasakan ketidakpuasan terhadap tubuh yang dimiliknya, selain itu juga adanya pengaruh significant other terutama yang berjenis kelamin sesama perempuan (ibu, saudara perempuan, teman perempuan) dalam mengingatkan seorang perempuan 
untuk mengevaluasi bentuk tubuhnya dengan melakukan perbandingan bentuk tubuh. Menurut Hurlock (2002) Perempuan yang mengalami ketidakpuasan diri karena sering membandingkan diri dengan yang lain, salah satunya adalah perempuan pada usia dewasa awal. Karena perempuan usia dewasa awal menyadari bahwa penampilan fisik yang menarik sangat penting untuk mencapai status sosial yang lebih tinggi terkait tugas perkembangan dewasa awal yang mencakup mendapatkan pekerjaan, memilih pasangan hidup, dan membentuk keluarga.

Ketidakpuasan tubuh dapat memunculkan berbagai macam masalah dimana masalah tersebut dapat berhubungan dengan kehidupan individu. Menurut Harlock (dalam Rohma, 2004) sejauhmana seorang individu dapat membentuk tingkah laku yang sesuai dengan nilai-nilai yang ada dilingkup kehidupannya dapat ditentukan dengan adanya penerimaan pada dirinya. Sejalan dengan pernyataan dari Sartain (dalam Rohma, 2004) yang menjelaskan bahwa dengan memiliki kesadaran untuk menerima diri, maka individu dapat mengenali diri sendiri dan akan mempunyai keinginan untuk terus mengembangkan dirinya. Penerimaan diri ini dapat terjadi pada usia dewasa awal karena masa dewasa awal ini merupakan masa dimana seseorang memiliki banyak kesempatan dan perubahan dalam segi kognitif dan social (Pratitis \& Hendriani , 2013). Menurut Perry (1970; dalam Santrock, 2002) ada beberapa perubahan penting tentang cara berpikir individu pada usia dewasa awal yang berbeda dengan remaja. Dewasa awal pemikirannya sudah lebih beragam dan sistematis, dalam pengambilan keputusan dapat lebih bijaksana, dapat toleransi erhadap hal-hal yang tidak diinginkan lebih meningkat, tidak hanya memikirkan kepentingan diri sendiri namun juga memikirkan kepentingan orang lain. Mereka merasa bahwa tubuhnya masih kurang memenuhi standart kecantikan yang ada, namun disisi lain mereka memiliki penerimaan diri yang cukup baik, sehingga dapat diketahui bahwa mereka memang merasakan ketidakpuasan terhadap tubuhnya namun masih dapat menerima diri karena mereka masih berpikir positif akan diri dan masa depannya. Hasil dari penelitian ini sejalan dengan penelitian yang dilakukan oleh Dewi (2017) pada penyandang disabilitas yang mengalami cacat fisik akibat kecelakaan, yang mana hasilnya menyatakan bahwa mereka para penyandang cacat fisik akibat kecelakaan ini merasakan ketidakpuasan terhadap fisiknya namun mereka masih mampu menerima dirinya. Awalnya memang tidak mudah bagi mereka untuk bisa menerima keadaan dalam dirinya namun karena adanya pemikiran positif yang muncul dari mereka sehingga mereka mampu menerima dirinya dalam keadaan yang sebelumnya tidak diharapkan olehnya. Berpikir positif adalah cara seseorang memandang segala persoalan yang muncul dari sudut pandang yang positif, karena dengan 
berpikir positif individu memiliki pandangan bahwa setiap permasalahan pasi ada jalan pemecahan dan suatu pemecahan masalah yang tepat dapat diperoleh melalui proses intelektual yang sehat (Peale, 1997; dalam Dewi, 2017). Sehingga saat mereka merasa tidak puas terhadap tubuhnya karena cacat fisik yang dialami mereka masih mampu menerima dirinya karena mereka menanamkan pemikiran-pemikiran yang positif. Karena jika seseorang mengalami cacat fisik akibat kecelakaan tidak memiliki pemikiran yang positif dan hanya didominasi oleh pemikiran-pemikiran yang negatif maka maka akan menghambat dirinya untuk dapat menerima diri dan kemampuannya.

Tentama (2014) mengemukakan bahwa semakin rendah kemampuan individu untuk berpikir secara positif, maka akan rendah pula penerimaan diri individu tersebut. Berpikir yang positif mampu membuat individu memusatkan perhatian pada hal-hal positif dari berbagai permasalahan yang dihadapi. Perempuan usia dewasa awal memang mengalami ketidakpuasan terhadap tubuh, tetapi mereka masih mampu menerima dirinya karena mereka memiliki cara dengan kamuflase-kamuflase terhadap tubuhnya sehingga masih mampu memiliki penerimaan diri yang baik. Saat ini memang telah banyak cara agar seseorang mampu menutupi kekurangan yang ada pada fisiknya, dari sini lah perempuan mampu menerima dirinya walaupun mengalami ketidakpuasan terhadap tubuhnya. Perempuan dalam usia dewasa awal memiliki cara berpikir yang logis sehingga dalam rasa ketidakpuasan terhadap tubuhnya mereka masih mampu menerima diri dengan cukup baik. Dari pemikirannya yang logis juga perempuan usia dewasa awal telah memiliki rasa bersyukur terhadap dirinya sehingga saat merasa kurang puas terhadap tubuhnya mereka masih mampu menerima dirinya dengan baik.

\section{KESIMPULAN}

Berdasarkan rumusan masalah, hipotesis, data hasil penelitian, serta pembahasan yang telah dijelaskan sebelumnya maka dapat ditarik kesimpulan bahwa tingkat ketidakpuasan tubuh dengan penerimaan diri pada perempuan usia dewasa awal (18 - 25 tahun) di kota Malang berada pada kaegori sedang. Hasil penelitian ini menunjukan bahwa ketidakpuasan tubuh berhubungan dengan penerimaan diri dengan nilai signifikasi $\mathrm{p}=0,024<0,05$ dengan nilai $0,226>r$ tabel 0,202. Penelitian ini membuktikan bahwa hipotesis diterima dengan rincian Ho ditolak dan Ha diterima.

\section{SARAN}

Berdasarkan dari kesimpulan, maka perempuan usia dewasa awal di Kota Malang ataupun juga di kota lainnya disarankan untuk lebih meningkatkan rasa kebersyukurannya baik rasa bersyukur terhadap dirinya 
sendiri maupun rasa bersyukur terhadap lingkungannya, dan juga mampu untuk meningkatkan kesehatan psikologisnya dengan cara meningkatkan dimensi-dimensi yang rendah pada aspek kesehatan psikologis, salah satu contohnya seperti lebih mampu mengontrol diri. Selain itu, ketidakpuasan terhadap tubuh perempuan usia dewasa awal juga sedang sehingga harus diturunkan agar menjadi rendah dengan cara mengurangi pada mengurangi penilaian negative terhadap tubuh sendiri dan mulai untuk meningkatkan keterbukaan diri terhadap orang lain dan mampu membangun hubungan baik dengan orang lain. Dan bagi peneliti selanjutnya hendaknya untuk menggali lagi mengenai variabel lain selain variabel yang telah diteliti dalam penelitian ini yang lebih berhubungan, sehingga mendapatkan banyak hal-hal lain yang tergali yang berhubungan dengan permasalahan perempuan usia dewasa awal.

\section{DAFTAR PUSTAKA}

Asih, D., \& Setiasih. (2004). Penerapan Metode Akupuntur pada Wanita Penyandang Obesitas. Anima: Psychological Journal. Vol. 19, No. 3.

Dewi, R. N. (2017). Penerimaan Diri pada Remaja Penyandang Disabilitas. Journal Fakultas Psikologi Universitas Ahmad Dahlan Yogyakarta. Vol. 2, No.3.

Gunarsa, S. D. (1999). Psikologi Remaja. Jakarta: BPK Gunung Mulia.

Hall, C. S., \& Lindzey, G. (1993). Psikologi Kepribadian I Teori-teori Psikodinamika. Yogyakarta: Penerbit Kanisius.

Hanum, R., Nurhayati, E., \& Nur, R. S. (2014). Pengaruh Body Dissatisfaction dan Self Esteem dengan Perilaku Diet. Journal Psikogenesis. Vol. 2, No. 2.

Hurlock, E. B. (2009). Psikologi Perkembangan: Suatu Pendekatan Sepanjang Ruang Kehidupan. Edisi 5. Jakarta: Erlangga.

Iswari, D., \& Hartini, N. (2005). Pengaruh Pelatiahan dan Evaluasi Self Talk terhadap Penurunan tingkat Body Dissatisfaction. Journal of Breeding and Genetics. Vol. 5, No.3

Meilinda, E. (2013). Hubungan antara Penerimaan Diri dengan Konformitasterhadap Intensi Merokok pada Remaja di SMK Istiqomah Muhammadiyah 4 Samarinda. eJournal Psikologi. Vol. 1, No. 1.

M. Lamont, Jean. (2018). Trait body shame predicts health outcomes in college women: A longitudinal investigation. Journal BehavMed. 
Nurhasyanah. (2012). Faktor-faktor yang mempengaruhi Penerimaan Diri pasa Wanita Infertilitas. Jurnal Penelitian dan Pengukuran Psikologi. Vol.1, No.2.

Pratitis, A. H., \& Hendriani , W. (2013). Proses Penerimaan Diri Perempuan Usia Dewasa Awal yang Mengalami Kekerasan pada Masa Anak-anak. Jurnal Kepribadian dan Sosial, 8.

Rizkiana, U. \& Retnaningsih. (2009). Penerimaan Diri Pada Remaja Penderita Leukimia. Jurnal Psikologi. Vol. 2, No. 2.

Risfani, S., Makmuroh, S. (2015). Hubungan Antara Body Dissatisfaction dengan Perilaku Diet Tidak Sehat Remaja Putri yang Menjadi Member Herbalife di Bandung. Fakultas Psikologi; Universitas Bandung.

Rohma, F. A. (2004). Pengaruh Pelatihan Harga Diri terhadap Penyesuaian Harga Diri pada Remaja. Indonesian Psychological Journal. Vol. 1, No. 1.

Santrock, J.W. (2002). Life-Span Development (Perkembangan Masa Hidup, Edisi Ketigabelas Jilid 2). Jakarta: Erlangga.

Sugiyono. (2016). Metode Penelitian : Kuantitatif, Kualitatif, dan R\&D. Bandung : Alfabeta CV.

Suniarto , L., Sukamto, M. E., \& Dianovinina, K. (2012). Social Comparison dan Body Dissatisfaction pada Wanita Dewasa Awal. Humanitas.

Supratiknya, A. (1995). Komunikasi Pribadi Tinjauan Psikologi. Yogyakarta: Penerbit Kanisisus.

Suprapto, M. H. \& Aditomo, A. (2007). Perbandingan Sosial, Body Dissatisfaction dan Objektifikasi Diri. Anima: Indonesian Psychological Journal. Vol. 22, No. (2).

Tentama, F. (2010). Berpikir Positif dan Penerimaan Diri paa remaja Penyandang Cacat Tubuh akibat Kecelakaan. Humanitas. VII(1).

Thompson, L. (2008). Mindfulness, Self-Esteem, And Unconditional SelfAcceptance. Journal of Rational-Emotive \& Cognitive-Behavior Therapy. Vol. 26, No. 2. 